\section{GEOLOGICAL WORK IN THE UNITED} STATES.

THE United States Geological Survey, under the directorship of G. Otis Smith, continues to discuss theoretical and practical problems from the most liberal point of view. T. Nelson Dale's account (Bulletin 589) of "Marble and Dolomite of Eastern Vermont" directs attention to a rose-coloured manganiferous calcite marble, "alternating in very small beds with equally small beds of fine-textured white dolomite." The author refers to his previous discussion of dolomite (Bull. 521), and suggests that the dolomite layers were precipitated inorganically, while the pink calcite layers received their manganese from organisms. Both the hard and soft parts of molluscs may contain appreciable percentages of manganese; but why should rose-coloured marbles be comparatively rare? The examples from Vermont lose their colour if used for external decoration.

In Monograph lxiii. F. Leverett and F. B. Taylor provide a detailed description of the "Pleistocene of Indiana and Michigan and the History of the Great Lakes." They conclude that the changes and deformations of shore-lines in this region may be due to crust-creep, as well as to alterations in the iceburden, but (p. 333) that the land is at present stable. The long eskers, formed during glacier-retreat in channels bounded by the ice, are excellently illustrated in the maps (see, for example, plate viii.), and the elaborate nature of the survey may be judged from the folded sheet, plate vii., where the moraines of the peninsula between Lake Michigan and Lake Hudson, with the lacustrine clays deposited behind them, are shown over a region measuring 300 by 200 miles. The Michigan Geological Survey has furnished important data for this memoir.

Bulletin 600 is a popular guide to the geology and scenery of "The Glacier National Park," Montana. The Continental Divide runs through the park, among peaks carved out of stratified rocks, which are from 9000 to $10,000 \mathrm{ft}$. in height, and some $6000 \mathrm{ft}$. above the valley-floors. A few residual glaciers still linger in the cirques. The region was originally purchased from the reservation of the Blackfeet Indians, in order to encourage copper-mining. The mines having proved unprofitable, the beauty of the country was represented to Congress in I9I0 (Fig. I). A good map accompanies this bulletin; but those who become interested in the folding and overthrusting and subsequent dissection of the strata of the park may like to learn more about their geological age than that they "are very, very old."

In North Park, Colorado (Bull. 596), lenticular masses of coal of extraordinary thickness occur in Upper Cretaceous or early Cainozoic strata. These coals may be 20,35 , or even $53 \mathrm{ft}$. thick, and are referred by A. L. Beekly (p. 94) to local marsh-areas, unconnected with one another, which encouraged rapid accumulation of vegetable or other organic matter. North Park is unfortunately bounded by a ring of mountains, away from trade-routes, and the remarkable cleanness of the coal is likely to prove its chief recommendation.

W. W. Attwood (Prof. Paper 95B) records and illus. trates a rather widely spread glacial boulder-clay of Eocene age in south-western Colorado. In a review of recorded "ice-ages," which excludes the evidences of mere valley-glaciers, the author finds no parallel with the Colorado instance, unless in the Eocene of North Italy. W. T. Lee (ibid., 95C) provides a possible source of the Eocene ice-flow in a review of the "Relation of the Cretaceous Formations to the Rocky Mountains in Colorado and New Mexico." He urges No. 2450 , VOL. 987 that all the Cretaceous coal-seams of the region, from Dakota times onward, were deposited on the margins and sometimes towards the centre of a single gradually subsiding shallow basin, which - (p. 57) reached from the Gulf of Mexico to the Arctic Ocean and from Utah to the Mississippi. The orogenic movement of Eocene times resuscitated the Rocky Mountain mass, which had been worn down and buried beneath these Cretaceous strata. Hence the beds which contain conglomerates derived from the newly raised mountains must all be regarded as of Cainozoic age. The folding experienced by the coalbearing strata during the uplift is well seen in the illustrations from Utah in Bulletin $58 \mathrm{IE}$.

From Nevada (Prof. Paper 95A) W. B. Hicks

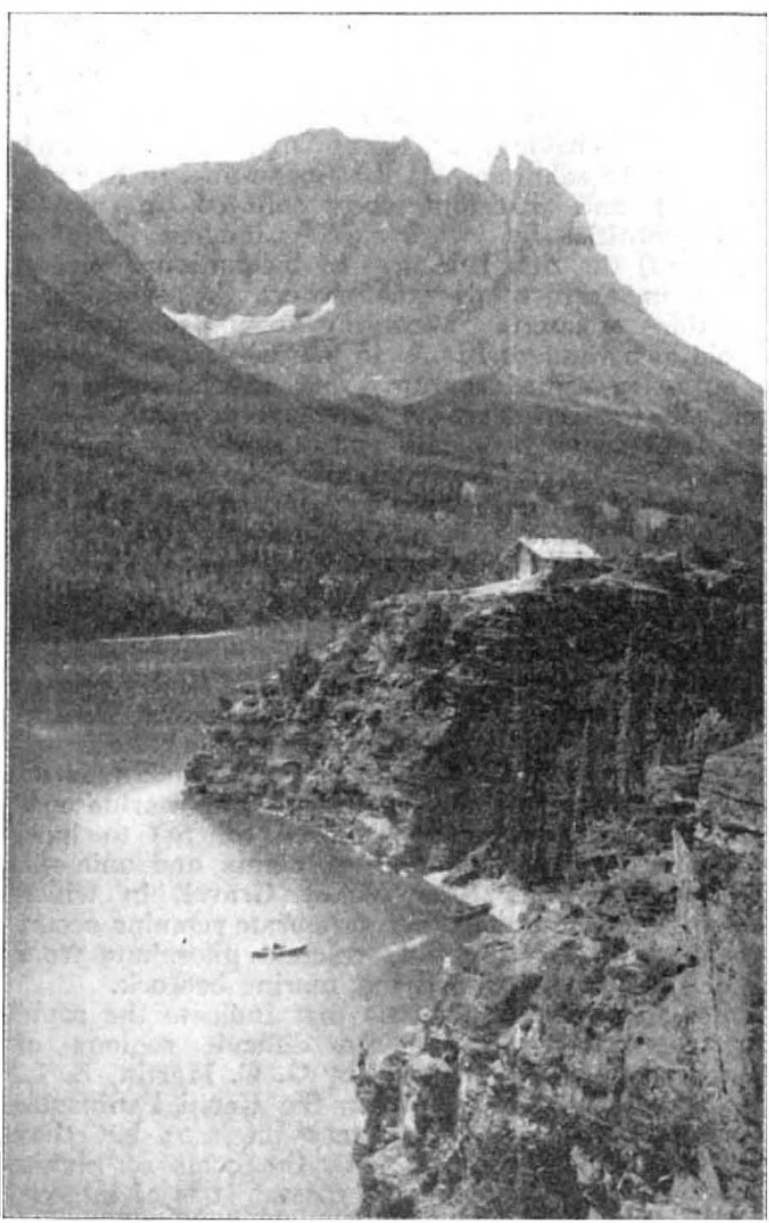
FIG. I.--St. Mary Lake and Red Eagle Mountain, Glacier National Park,
Montana.

draws interesting conclusions as to the apparent disappearance of potassium from the brines and saline deposits of the desert-basin regions. High percentages of potassium are obtained by boiling the muds of Columbus Marsh with water, and the author believes (p. 9) that these muds have withdrawn potash from percolating solutions, holding it in virtue of their colloids or in a weak chemical combination. Only a small proportion of the potash can be referred to extraction from the mud-forming minerals, and (p. 8) "the potash content of the muds is roughly constant without regard to the character of the material," i.e. whether this is sand or clay. The retention of potash by soil-particles has, of course, been discussed by 
agricultural investigators, and it here receives a wide geological application. Hoyt S. Gale, in describing (Bull. $580 \mathrm{~L}$ ) the salines of Borax or Searles Lake, San Bernardino Co., California, touches on the same point, and regards the preservation of potassium chloride in the brine of this lake-area as quite exceptional. The analysis quoted on p. 294 of his paper; on which so much depends (see p. 31I), seems to have gone far astray. Should we read 12.30 for the percentage of potassium chloride, in place of 1.50 ? The author's well-illustrated account of the salts crystallised in this desiccating region forms a convenient synopsis for students of mineralogy. Bull. 603 is of interest from the evidence given that the mineral oils north of Coalinga, California, originated in the decay of diatoms of Upper Cretaceous age.

In discussing a "Gold-Platinum-Palladium Lode in Southern Nevada" (Bull. 620A), Adolph Knopf reviews the known occurrences of platinum, and points out that this metal may be reasonably looked for in copper ores, having, as Kemp suggested, migrated with them in solution. At the Boss Mine, in Nevada, the gold and platinum occur alloyed in almost equal quantities by weight. W. Lindgren describes (Bull. 6oI) the rich gold ores of the national mining district in northern Nevada, where the exceptional attractions of quartz "averaging about $\$ 30,000$ a ton in gold of a value of $\$ 10.60$ an ounce "led, as recently as 1912, to armed alarums and excursions of the good old western type. A defensive searchlight has been kept playing on the entrance of the National Mine. Outside the National lode, the veins contain silver and antimony ores; but all the minerals are probably connected in depth, as products of ephemeral hot springs at a late stage in the eruption of Cainozoic (Miocene?) rhyolites.

G. C. Matson's description (Bull, 604) of "The Phosphate Deposits of Florida" is accompanied by a large coloured geological map of the State, on the scale of I : I, 000,000. The most interesting feature of this is the famous Florida East Coast Railroad, which steps from isle to isle of coral, and ends on the Pleistocene oolite of Key West. The marine concretionary phosphates are believed (p. 64) to have originated from the remains of plants and animals, while the fluviatile Bone Valley Gravel, in which teeth of Mastodon and other vertebrate remains occur, is held to have received its calcium phosphate from the detritus of the underlying marine bedrock.

Among several publications that indicate the rapid progress of surveying in the difficult regions of Alaska, we note Bulletin 587 , by G. C. Martin, B. L. Johnson, and U. S. Grant, on the Kenai Peninsula. Cainozoic coal-seams occur near the sea; but they seem unlikely to compete with the coals of higher grade available on the Pacific coast. It is of interest to find (p. 52) a series of "green scoriaceous and ellipsoidal lavas" of Triassic age overlain by radiolarian cherts. Once more we see that a particular marine condition has brought about the formation of these two dissimilar rock-types, though the clear evidence of succession in this case prevents our ascribing the abundance of radiolarians to the emanation of silica from the lavas. The detailed work by C. W. Wright on Copper Mountain and Kasaan Peninsula (Prof. Paper 87) includes well-illustrated observations on contact-metamorphism. Some of the aplite veins (p. 8I) contain as much as 9 per cent. of primary calcite; a mineral that has already taken its place as an original constituent of igneous rocks. S. R. Capps (ibid., 95D) traces the volcanic ash layer of the Yukon basin to a "centre of dispersion," by no means central, north of Mount Logan. At this point the deposit is $300 \mathrm{ft}$. thick, fading away to a foot in about 150 miles to eastward. The layer is traceable over 140,000 square miles, and, from the thickness of peat above it on the White River, is ascribed to an eruption that took place on the north of the Mount St. Elias region about r 400 years ago. The report by A. H. Brooks, who superintends' the surveying work in Alaska, on the mineral resources of the region in 1914 (Bulletin 622) includes an unfavourable judgment on some of the coals from the point of view of the Navy Department; the coal of the Matanuska field, however, is regarded as of excellent steaming quality, and the progress of goldmining, the great industry of Alaska, may possibly open up this field.

W. B. Clark and M. W. Twitchell have written a monograph on "The Mesozoic and Cenozoic Echinodermata of the United States" (Monograph liv.), illustrated with 108 plates of drawings and direct photographs. While the genera are for the most part of world-wide occurrence, few of the familiar European species are found in American deposits. F. W. Clarke and W. C. Wheeler (Prof. Paper goL) follow up their work on the composition of crinoid skeletons by an examination of the hard parts of other recent echinoderms, Magnesium carbonate is found in these also; the quantity is large in tropical forms as compared with those from cold waters, and may reach $\mathrm{i} 4$ per cent. The authors conclude that a rock formed from any kind of echinoderm "will have the composition of a moderately magnesian limestone." As previous workers have pointed out, the calcium carbonate of echinoderms is always in the calcite form.

Mineralogists and chemists will alike appreciate F. W. Clarke's essay on "The Constitution of the Natural Silicates" (Bull. 588), in which consideration is given to their alteration-products, as suggesting the structure of the molecule of the original mineral. The treatment of spodumene (p. 98) serves as an interesting example, and leads on to new interpretations of the pyroxenes and the amphiboles, which are worked out as mixtures of orthosilicates and trisilicates, while wollastonite and pectolite, which are easily decomposed by dilute acids, remain isolated as metasilicates. Whitman Cross (Prof. Paper 88) enlarges our imperfect knowledge of "The Lavas of Hawaii and their Relations," covering the Hawaian Islands as a whole. The mountain-chain of which these are the unsubmerged peaks extends for 1800 miles in a northnorth-westerly direction. The rock-types offer no support to the suggestion of a distinctively Pacific group of igneous rocks, or a group produced under Pacific conditions, and the alkalic and calcic rocks of Rosenbusch occur in the islands (p. 86) as derivatives from a common source. The author doubts (p. 9o) Daly's view that limestone has had an influence in promoting the occurrence of the types rich in alkalis. His visit to the islands in 1902 enables him to review his specimens as parts of some of the most striking volcanic landscapes in the world.

The twenty-third volume of the Iowa Geological Survey (I9I4) consists of O. P. Hay's monograph on "The Pleistocene Mammals of Iowa," the remains being found in interglacial beds. The Aftonian stage, following the first Glacial or Nebraskan stage, is especially the horizon of Mylodon, in North America, and of the last North American Camelidæ. The memoir is fully illustrated. R. S. Lull reviews (American Journal of Science, vol. xl., I9I5, p. 3I9) "The Mammals and Horned Dinosaurs of the Lance Formation of Niobrara County, Wyoming," and shows that mammalian remains, including throughout the older multituberculate types, are found in almost all the beds that contain Ceratopsia. The triNo. 2450 , VOL. 98$]$ 
tuberculate mammals occur, however, on the upper horizons, and may still have existing representatives. H. F. Osborn discusses the "Close of Jurassic and Opening of Cretaceous Time in North America" (Bull. Geol. Soc. America, vol. xxvi., I9I5, p. 295), as an introduction to a symposium on the Morrison formation. This discussion has a special application in England to the Purbeck-Wealden question.

The Wisconsin Geological and Natural History Survey has reported on the north-western area of the State (Bulletin No. 45, Madison, I9I5), where very little geological work had been done prior to the official entry of Mr. W. O. Hotchkiss and his assistants in I913. Since the area lies in the Lake Superior iron district, great stress has been laid upon a continuous magnetic survey, the principles of which are set out in chapter iv. This illustrated essay of sixty pages will be of service to mining students in general. The ores are the well-known sedimentary masses of Huronian age, and the extent of the Huronian beds beneath the glacial drift has been largely determined by magnetic readings. Bush-covered ground and rivers, as indicated in the sympathetic pictures of geologists at work, have often hindered observation, and only the most careful organisation could have carried out the survey in so comparatively short a time.

G. A. J. C.

THE ZOOLOGICAL SURVEY OF INDIA. $W^{\text {ITH }}$ the sanction of the Secretary of State the Government of India has recently converted the professional staff and entire working machinery of the zoological section of the Indian Museum into an autonomous Government department, under the name and style of the Zoological Survey of India.

This conversion, if it were-as to superficial view it might appear-merely a change of name, could pass without comment in a momentous time like the present; but inasmuch as it effects a long-desired and fundamental improvement in the prospects and official status of zoology in India-a country where, private enterprise in the domain of natural science being undeveloped, no branch of science that lacks independent and avowed recognition in the highest official quarters can hope to expand to its full extent-it deserves some notice.

In times not very long past the zoological section of the Indian Museum was administered by trustees, on the model of the British Museum, an arrangement illsuited to a polity where, outside official circles, trustees with the necessary academic experience are not easy to find. One of the most unsatisfactory results of this system was that, although all ate of one salt and owned the Government as their father and mother, the zoological officers-irrespective of professional seniority or length of service-had always to be the official subordinates of their confrères in kindred scientific departments, who were constantly associated with the museum as trustees.

This anomaly was rectified by making the senior zoological officer eligible for the office of trustee, a resort to legal fiction which, although it placed zoology in proper official perspective, was calculated to offend tender consciences.

All such fictions are now obviated by bringing the whole zoological staff and its appurtenance into line with other scientific departments of the Government of India, and placing the senior representative of zoology on the same footing as the directors of the kindred scientific surveys-a position in which his opportunities of advocating and initiating research are much augmented and his responsibilities as an independent scientific adviser to Government are distinct and direct.

No. 2450 , VOL. 98$]$
In notifying this auspicious change the Government expresses the hope that the establishment of a zoological survey will be of value to India; and when it is remembered-apart from all the economic reflections of the matter-that in territories like India more than 75 per cent. of the annual mortality is due either directly or proximately to noxious animals and animal. cules, so that rural sanitation in such countries must rest in the first instance upon accurate and comprehensive zoological foundations, there seems every assurance that this hope will be justified.

Apart from these internal changes, which bring field-work from a precarious position in the rear into the very front rank of the duties of the staff, and transform the trustees from responsible guardians into authorised visitors of the collections, the zoological section of the museum as a going concern will not be altered in any way. Nor is any extra expenditure anticipated for the immediate future, since the available museum grant is ample for the intended purpose, and the collaboration of the Marine Survey Department and the close co-operation of the Forest and Agricultural Departments are assured.

Under the new régime the national zoological museum of India promises to be, like some other Indian official organisations, an institution of an exemplary kind.

\section{GENETIC STUDIES IN PLANTS.}

$\mathrm{IN}$ a paper on "Growth and Variation in Maize" (Zeitschr. f. indukt. Abstammungs- und Vererbungslehre, xiv., 1915, Nos. 3-4), Drs. Raymond Pearl and F. M. Surface combine the statistical and individual methods of inquiry. "We have tried," they write, "by studying the growth of the individual to analyse the adult variation curve into its component elements." Height is the character chosen for investigation; the relative variability as observed throughout the season "shows a marked progressive diminution," and the authors believe that the maize plant grows "in a series of cycles." In a second part of the paper they discuss the relation of variation to growth, and from the distribution of small, medium, and large plants conclude that the manner of growth is dependent on Mendelian factors.

Maize is also the subject of a paper in the Journ. Agric. Research (vi., No. I2) by G. N. Collins, who deals with "correlated characters" in the species. Eleven characters were selected for study, and of fiftyfive possible combinations twenty were found to show significant correlations; but in all but five these appear to be physiological rather than genetic, and in no instance is the coefficient higher than 0.5 . The author fears, therefore, that the method of isolating types is inapplicable to maize, though desirable characters derived from different parents may be easily combined.

The "Suppression of Characters on Crossing," illustrated by experiments on species of wheat, is discussed in a paper by R. H. Biffen (Journ. of Genetics, v., No. 4). He finds that dominant features, such as greyness of chaff or redness of grain, may be suppressed, so that "recessives make their appearance in $F_{2}$ generations from crosses of parents showing dominant characters only." This may perhaps be due to the existence of more than one factor giving rise to apparently the same dominant character, and the consequent possibility that two factors determining the recessive may meet in some of the zygotes that give rise to the $F_{2}$ generation.

Dr. T. Tammes contributes a paper to the Proceedings (xviii., No. 7) of the Kon. Akad, v. Wetensch. Amsterdam "On the Mutual Effect of Genotypic Factors." She has experimented by crossing varieties of flax differing in colour (blue or white) and breadth 